\title{
Volatile Free Fatty Acids as Ripening Indicators for Serra da Estrela Cheese
}

\author{
F. K. Tavaria, A. C. Silva Ferreira, and F. Xavier Malcata \\ Escola Superior de Biotecnologia, Universidade Católica Portuguesa, \\ Rua Dr. António Bernardino de Almeida, Porto, Portugal
}

\section{ABSTRACT}

Serra da Estrela cheese is an artisanal cheese manufactured from raw ewe's milk coagulated with Cynara cardunculus; it is highly appreciated for its unique flavor and bouquet. This research effort focused on a search for the molecules responsible for those organoleptic characteristics. Eighty cheeses manufactured in 4 dairies located in the Appélation d'Origine Protegée region of Serra da Estrela, Portugal, were thus assayed for volatiles, in an attempt to characterize their odorous profile. Cheeses were analyzed from the time of manufacture up to $180 \mathrm{~d}$ of ripening. The volatile fraction was assayed by solid phase microextraction-gas chromatography/mass spectroscopy, and several compounds belonging to different chemical groups (e.g., fatty acids, esters, carbonyl compounds, pyrazines, and sulfur compounds) were detected in that traditional cheese. Among these, free fatty acids (FFA) were quantitatively the dominant family present. Furthermore, sensory descriptors for the typical aroma of this cheese included acidic, sweaty, and sheepy-like. Acetic, isobutyric, and isovaleric acids increased in concentration during the ripening process up to $90 \mathrm{~d}$, and remained constant thereafter. Preliminary sensory analysis was performed by addition of the major FFA to an unripened cheese matrix; results showed that they could successfully be used as ripening indicators for this cheese. Such key molecules may thus be used to monitor ripening, and hence find the optimal consumption time for this gourmet dairy product.

(Key words: solid phase microextraction, dairy foods, gas chromatography-mass spectroscopy, sensory analysis)

Abbreviation key: GCMS = gas chromatography/ mass spectroscopy, $\mathbf{O A V}=$ odor activity value, $\mathbf{S P M E}=$ solid phase microextraction.

Received April 15, 2004.

Accepted July 28, 2004.

Corresponding author: F. X. Malcata; e-mail: fxmalcata@esb. ucp.pt.

\section{INTRODUCTION}

Cheese is a complex matrix, the chemical features of which depend on the combined influence of several factors (e.g., $\mathrm{pH}$, temperature, water activity, and microflora) throughout ripening. Furthermore, its sensory characteristics result from a dynamic interaction of chemical and microbiological parameters. It is well documented (Buchin et al., 1998) that cheeses manufactured from raw milk acquire a more intense flavor than those produced from pasteurized or heat-treated milks; such realization is mainly due to the high levels of native lactic acid bacteria present in raw milk (Grapin and Beuvier, 1997). As a consequence, variability is a major drawback in cheeses manufactured from raw milk, which is accounted for (among other causes) by seasonal variations in their indigenous microflora. This is the typical case of Serra da Estrela cheese, an artisanal raw (ewe's) milk cheese, coagulated with plant rennet without deliberate addition of any starter culture, which is produced in Portugal at approximately $1200 \mathrm{ton} / \mathrm{yr}$, where it is by far the most famous traditional cheese.

Processes that minimize the aforementioned variability are urged, so as to not only improve microbiological safety but also to guarantee a final product bearing typical aroma attributes, on both artisanal and industrial levels. The addition of native cultures (Centeno et al., 1996, 1999; Menéndez et al., 1999, 2000) may be a way to reduce the heterogeneous quality of cheese. However, a priori knowledge on the molecules responsible for the unique organoleptic attributes of each particular cheese is in order; very few studies have meanwhile been published concerning the volatile compounds in Serra da Estrela cheese (Partidário et al., 1998), or other Portuguese ewe's cheeses (Pinho et al., 2001).

From a sensory perspective, odor descriptors associated with typical aroma of Serra da Estrela cheese are "acidic," "sweaty," and "sheepy-like" notes, as described in the Portuguese legal standard (NP-1922, 1985). These descriptors suggest that FFA play a major role in the aroma character of this cheese; hence, its FFA profile could be used to help establish the optimum ripening time for this cheese, defined as that providing 
the aroma attributes qualitatively and quantitatively mostly appreciated by consumers. A wide array of volatiles, for example, alcohols, esters, ketones, aldehydes, and FFA, are among the families of compounds reported to be present in cheeses manufactured from ewe's milk (Ortigosa et al., 2001; di Cagno et al., 2003; Muñoz et al., 2003). Among those, short-chain FFA are usually present to relatively high levels (Dirinck and de Winne, 1999; Akin et al., 2003), and are thus considered important owing to their aroma impact in the final product.

The primary aim of this research effort was to improve the extraction method of volatiles from the cheese matrix, and then characterize the volatile fraction of Serra da Estrela cheese throughout ripening. The second aim was to conduct preliminary sensory studies to determine which, among the most abundant molecules, exhibit the highest aroma impact.

\section{MATERIALS AND METHODS}

\section{Cheese Manufacture}

Serra da Estrela cheese was manufactured in 4 dairy farms scattered throughout the Appélation d'Origine Protegée (AOP) region from raw ewe's milk coagulated with Cynara cardunculus extracts, according to the traditional protocol described by Tavaria and Malcata (1998). Each dairy produced 20 cheeses from the same batch of milk and, at each ripening time $(0,3,7,18$, $35,60,90,120,150$, and $180 \mathrm{~d}), 2$ cheeses at random were brought under refrigerated conditions $\left(4\right.$ to $\left.5^{\circ} \mathrm{C}\right)$ to our laboratory, where they were kept at $-30^{\circ} \mathrm{C}$ until further chemical analyses.

\section{Chemicals}

Propionic, butyric, isovaleric, isobutyric, caproic, caprylic, capric, and lauric acids, as well as ethyl butanoate, hexanoate, octanoate, decanoate, and dodecanoate (purity: 99\%) were purchased from Sigma Chemical Co. (St. Louis, MO); acetic acid (purity: 96\%) was from Merck (Darmstadt, Germany).

\section{Sample Preparation and Volatile Analysis}

At each selected ripening time, $20 \mathrm{~g}$ of cheese from each dairy was macerated using a mortar and pestle and thoroughly mixed. From this mixture, a 10-g aliquot was then taken for volatile analysis. The cheese was homogenized using a sterile plastic bag in a stomacher laboratory blender 400 (from Seward Medical, London, UK) for $2 \mathrm{~min}$. This sample was then put in a 100 -mL flask capped with a gas-tight seal, at a constant temperature of $45^{\circ} \mathrm{C}$. A volume of $100 \mu \mathrm{L}$ of an internal standard, octan-3-ol, in a 1:1 (vol/vol) hydro-alcoholic solution at $461.97 \mathrm{mg} / \mathrm{L}$ was added, and the sample was gently stirred (100 rpm) using a stirring bar during volatile collection. After equilibration, the solid phase microextraction (SPME) fiber assembly of choice, containing a divinylbenzene/carboxen/polydimethylsiloxane (DVB/CAR/PDMS) fiber coating (Supelco, Bellefonte, PA) was introduced, and left for $1 \mathrm{~h}$ to trap volatiles. After this period, the fiber was introduced in the injector port and left to desorb trapped volatiles for $10 \mathrm{~min}$.

\section{Method Development}

As a solid matrix, cheese poses sampling problems owing to heterogeneity and geometrical constraints, which affect reproducibility of the quantitative results. To increase homogeneity, and hence maximize extraction, 2 temperatures were tested; the higher temperature (at which no artifact formation was observed) was then safely chosen. Furthermore, 3 types of fibers were tested, and the best exposure time was sought, as described in detail in the following sections.

\section{Artifact Formation}

It is well documented (Pérès et al., 2002) that high temperatures may produce artifacts because new compounds may form via chemical reactions induced by heating. To ascertain whether such degree of heating would produce artifacts, 3 samples were compared: (1) a sample of cheese was analyzed as described above, by equilibrating the sample at $25^{\circ} \mathrm{C}$ instead of $45^{\circ} \mathrm{C}$; (2) the sample was then heated up to $45^{\circ} \mathrm{C}$, allowed to equilibrate at that temperature and sampled after $1 \mathrm{~h}$ of exposure to the fiber; and (3) the sample was allowed to cool to $25^{\circ} \mathrm{C}$ and sampled again. These measurements were repeated 3 times.

\section{Choice of Fiber}

The fibers tested for volatile extraction were: polyacrylate (PA) $85 \mu \mathrm{m}$, carboxen/polydimethylsiloxane (CAR/PDMS) $75 \mu \mathrm{m}$, and divinylbenzene/carboxen/ PDMS (DVB/CAR/PDMS) 50 to $30 \mu \mathrm{m}$ (from Supelco, Bellafonte, PA). Comparative performance of these fibers was assessed using ripened Serra da Estrela cheese. The volatile components were extracted via SPME by exposing the fibers for $60 \mathrm{~min}$ in the cheese headspace, inside a flask maintained at a constant temperature of $45^{\circ} \mathrm{C}$.

\section{Exposure Time}

The adsorption kinetics was determined for 6 exposure times $(15,30,45,60,90$, and $120 \mathrm{~min})$ of the fiber in 
the headspace. Each measurement was repeated twice. The optimum exposure time was determined as the time at which the peaks were highest in area accounted for by the compounds of interest.

\section{Reproducibility and Linearity}

Volatiles from ripened Serra da Estrela cheese were extracted using the optimal conditions found for the several parameters tested (fiber, exposure time, and extraction temperature), and analyzed by gas chromatography/mass spectroscopy (GCMS). The coefficient of variation $[\mathrm{CV} \%=(\mathrm{SD} / \mathrm{mean}) \times 100]$ was determined for all compounds quantified. This was repeated 6 times. The effects of the various parameters upon extraction efficiency were determined using intensity and number of mass fragments obtained, as well as coefficient of variation of the measurements. Standard curves were prepared for each such compound by injecting increasing volumes $(20,40,60,80,160,320$, and $1000 \mu \mathrm{L})$ of a mixture containing known amounts of those compounds, using unripened cheese as matrix. The values of $\mathrm{K}$ (partition coefficient) and $\mathrm{r}$ (correlation coefficient) were determined from these curves.

\section{GCMS Conditions}

Volatiles were thermally desorbed in the injector port $\left(220^{\circ} \mathrm{C}\right)$ in splitless mode, and analyzed using a Thermo Quest Trace GC 2000 series gas chromatograph, equipped with a GCQ mass detector (Finnigan Mat, San Jose, CA). The split valve was opened $30 \mathrm{~s}$ after injection. Volatile compounds were separated in a 50$\mathrm{m}$ FFAP (CP-Wax 58) column $(0.25 \mathrm{~mm} \times 0.39 \mathrm{~mm} \times$ $0.20 \mu \mathrm{m}$ ) (Varian-Chrompack, Walnut Creek, CA). The oven temperature was held at $40^{\circ} \mathrm{C}$ for $1 \mathrm{~min}$, and then increased at $2^{\circ} \mathrm{C} / \mathrm{min}$ up to a final temperature of $220^{\circ} \mathrm{C}$, which was held for $30 \mathrm{~min}$. All mass spectra were acquired in electron impact mode. The carrier gas was helium C-60 (Gasin, Portugal), at a constant volumetric flow rate of $1 \mathrm{~mL} / \mathrm{min}$. The transfer line and source temperatures were 190 and $180^{\circ} \mathrm{C}$, respectively. The emission current was $70 \mathrm{mV}$, and the electron multiplier was set according to the autotune procedure. The mass range was 29 to $350 \mathrm{~m} / \mathrm{z}$, with a scan rate of 7 $\mathrm{scan} / \mathrm{s}$. All analyses were carried out in full scan mode. Identification was achieved via comparison of the mass spectra obtained for a sample containing a mixture of pure standards injected under the same conditions to the mass spectra of the NIST 98 MS library database (or others available in the literature). The DM content of the cheese samples was determined according to the standard procedure of FIL-IDF (1982), and the results were expressed on a DM basis.

\section{Sensory Analysis}

Odor activity values (OAV) were calculated as concentration of compound/odor threshold for all shortchain FFA. The 2 FFA with the highest OAV (i.e., butyric and isovaleric acids), as well as a third compound believed to have no impact on the sensory perception of this cheese (i.e., ethyl hexanoate, an ethyl ester) were used in this analysis.

The aforementioned compounds were added independently, or in combination to $10 \mathrm{~g}$ of unripened cheese, at the amounts found in the reference sample (60-d-old cheese): $3.18 \mathrm{mg} / \mathrm{kg}$ ethyl hexanoate, and 442.58 and $601.03 \mathrm{mg} / \mathrm{kg}$ butyric and isovaleric acids, respectively. Samples were homogenized by stirring, and the individual flasks were covered with aluminum foil. Sets of 8 samples were presented to a panel of 12 people for odor assessment only. The control sample consisted of unripened curd, that is, curdled ewe's milk without any compound added. Three samples were added with each compound independently, 3 samples were added with pair combinations of the 3 compounds, and another sample was added with the combination of all 3 compounds. After the corresponding additions, samples were homogenized by stirring, and the individual flasks were covered with aluminum foil. The panel rated the odor of the samples by comparison to the reference sample of ripened cheese, using a 0 to 10 scale (where 0 means no similarity whatsoever, and 10 means equal to the matured sample). Experiments were carried out in individual booths at room temperature $\left(\sim 18\right.$ to $\left.20^{\circ} \mathrm{C}\right)$. The experiment was repeated 4 times.

\section{Statistical Analyses}

Statistical analysis of the volatile data was performed using the SPSS statistical package (version 11.5 for Windows, from SPSS, Chicago, IL) via ANOVA, at a degree of significance of $\alpha=0.05$. ANOVA was carried out so as to infer on the significance of the effect of ripening time on volatile formation; posthoc multiple comparisons were done using Tukey's test ( $\alpha=0.05)$, after having performed tests that confirmed a normal distribution of the data. For the sensory data, the distribution was not normal even after simple data transformation, so these were analyzed using the nonparametric approach of Wilcoxon Signed Ranks test for pairwise comparisons and determination of homogeneous subsets. The appropriate correction for the Bonferroni's multiple comparison was carried out with $\alpha_{\beta}=0.005$.

\section{RESULTS AND DISCUSSION}

\section{Reproducibility and Linearity}

The coefficient of variation (determined over 6 analytical cheese replicates) for each compound quantified 
Table 1. Normalized peak area (of 6 replicates): average, standard deviation, and coefficient of variation, pertaining to major short-chain FFA and ethyl esters in Serra da Estrela cheese by $180 \mathrm{~d}$ of ripening, determined by the solid phase microextraction (SPME) method.

\begin{tabular}{lrlr}
\hline Compound & Average & SD & \multicolumn{1}{c}{ CV } \\
\hline Acetic acid $\left(\mathrm{C}_{2}\right)$ & 6.32 & \pm 1.34 & 21.19 \\
Butyric acid $\left(\mathrm{C}_{4}\right)$ & 17.25 & \pm 2.47 & 14.33 \\
Isovaleric acid $\left(\mathrm{iC}_{5}\right)$ & 5.85 & \pm 0.64 & 10.95 \\
Caproic acid $\left(\mathrm{C}_{6}\right)$ & 15.55 & \pm 1.51 & 9.71 \\
Caprylic acid $\left(\mathrm{C}_{8}\right)$ & 8.79 & \pm 0.77 & 8.76 \\
Ethyl hexanoate $\left(\mathrm{C}_{6} \mathrm{C}_{2}\right)$ & 0.59 & \pm 0.05 & 8.28 \\
Ethyl octanoate $\left(\mathrm{C}_{8} \mathrm{C}_{2}\right)$ & 0.98 & \pm 0.09 & 9.47 \\
Ethyl decanoate $\left(\mathrm{C}_{10} \mathrm{C}_{2}\right)$ & 1.16 & \pm 0.15 & 12.84 \\
Ethyl dodecanoate $\left(\mathrm{C}_{12} \mathrm{C}_{2}\right)$ & 0.37 & \pm 0.04 & 10.77 \\
\hline
\end{tabular}

ranged from 8 to $21 \%$, as shown in Table 1 . The method was linear for the compounds tested, with r-values ranging from 0.990 to 1.000 .

\section{Artifact Formation}

Overlapping of the 3 chromatograms (Figure 1) indicates that, despite the 2 -fold rise in some peaks (e.g., $\mathrm{C}_{4}$ and $\mathrm{C}_{6}$ ) caused by the temperature increase (Figure 1b), no new peaks are formed. Hence, it could be inferred that the temperature used was a good way to increase the extractability of the dominant compounds, without concomitant generation of unwanted artifacts.

\section{Choice of Fiber}

Comparison of the performance of the 3 fibers tested proved that the chromatographic information obtained was both qualitatively (number of compounds) and quantitatively (chromatogram peak area) higher after extraction using the DVB/CAR/PDMS fiber than using the other 2 alternative fibers. The polar characteristics of most volatile compounds likely contribute to make the DVB/CAR/PDMS fiber the best type of trapping support. Note that carboxen/PDMS has been shown (Lawlor et al., 2002) to be efficient in trapping shortchain FFA, whereas PDMS/DVB has a greater affinity for higher molecular weight FFA. Consequently, choice of the fiber containing the 3 types of support led to the best results.

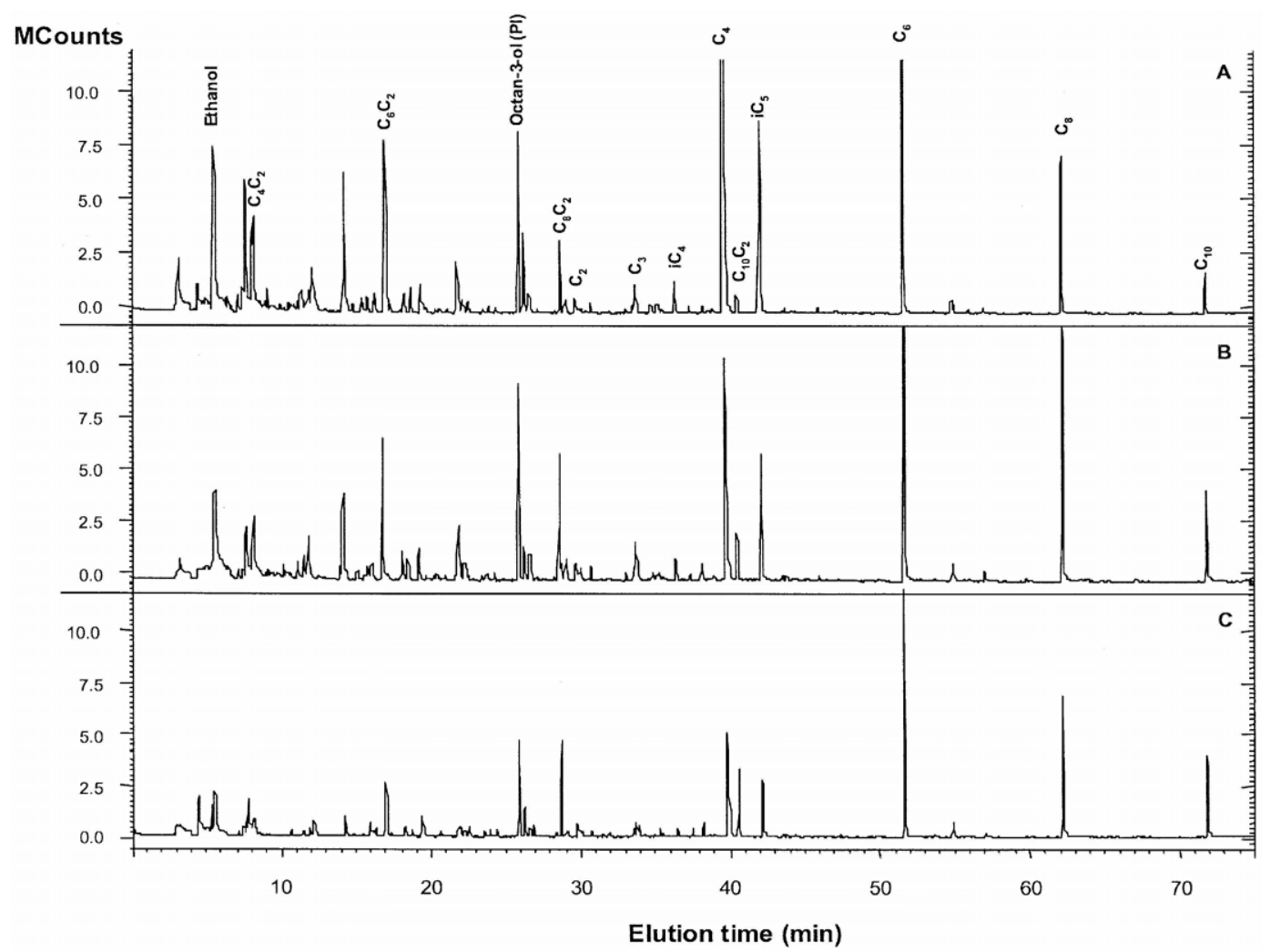

Figure 1. Representative chromatograms of a given sample, assayed by gas chromatography-mass spectroscopy (GCMS) according to different temperature patterns for a given exposure time (60 min): A. Exposure to $25^{\circ} \mathrm{C}$; B. Exposure to $45^{\circ} \mathrm{C}$; and $\mathrm{C}$. Exposure to $45^{\circ} \mathrm{C}$ ( 60 $\min$ ), cooling down to $25^{\circ} \mathrm{C}$, and exposure to $25^{\circ} \mathrm{C}(60 \mathrm{~min})$. 


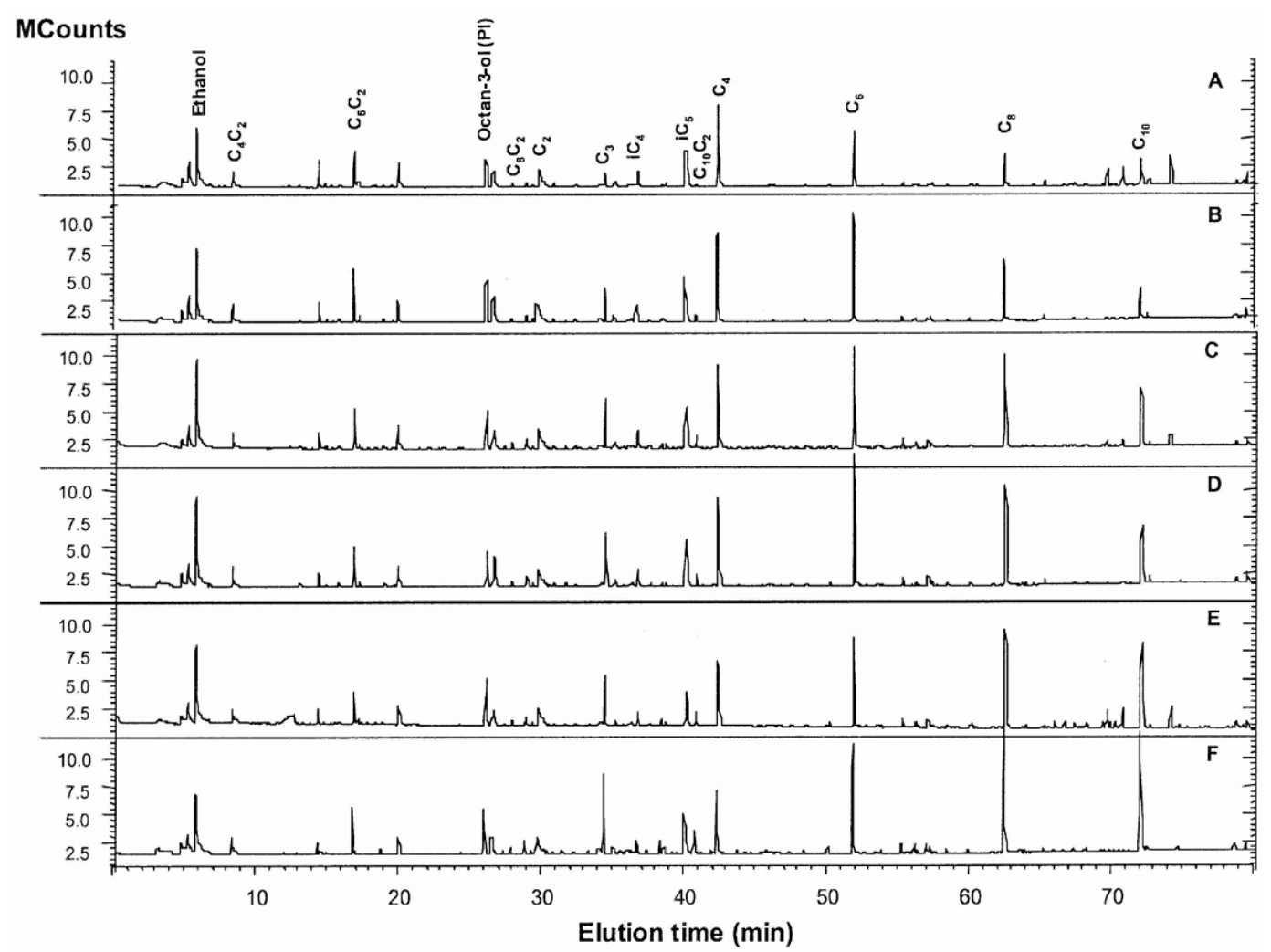

Figure 2. Representative chromatograms of samples, assayed by gas chromatography-mass spectroscopy (GC-MS), for various exposure times of the divinylbenzene/carboxen/polydimethylsiloxane (DVB/CAR/PDMS) fiber. Exposure for: A. 15 min; B. 30 min; C. 45 min; D. 60 min; E. 90 min; and F. 120 min.

\section{Exposure Time}

Inspection of Figure 2 points at an increase in peak intensity with increasing exposure time of the fiber assembly, as expected. After 60 min (Figure 2d), however, such an increase was no longer significant, so $60 \mathrm{~min}$ was chosen as the optimum exposure time for volatile extraction.

\section{Volatile Analysis}

Serra da Estrela cheese possesses a few unique features that render it quite different from other cheeses produced industrially using pasteurized or heat-treated cow's milk. First, it is manufactured from raw ewe's milk, which has almost twice as much fat as cow's milk (7.1 vs. 3.8\%) (Biss, 1991). Similarly, the total fatty acid amount in sheep's milk is $\sim 4.3 \mathrm{~g} / 100 \mathrm{~g}$, whereas in cow's milk it is $2.0 \mathrm{~g} / 100 \mathrm{~g}$. The microbial load is quite high by the time of manufacture, especially in terms of Enterobacteriaceae, which are known to produce lipases that breakdown milk fat, when compared with other cheeses manufactured from heat-treated milk. Second, the coagulant used in cheese making is a crude protease mixture of plant origin, which acts only upon the proteinaceous fraction of milk (unlike commercial rennets, which usually bear a strong lipolytic capacity). Third, ripening takes place at a relatively low temperature (8 to $10^{\circ} \mathrm{C}$ ), which does not favor lipolysis.

The volatile profile of Serra da Estrela cheese during ripening, as determined by SPME, is depicted in Table 2 . Relative amounts are expressed as normalized peak areas (peak area/peak area of internal standard), on a DM basis. ANOVA of the profile of volatiles indicated that ripening time was a statistically significant $(P<$ 0.05 ) parameter toward formation of most compoundsmajor families comprised ketones, pyrazines, alcohols, aldehydes, phenolic compounds, ethyl esters, and FFA. Among these, the significance and impact of FFA, owing to their relative amounts, upon the overall aroma is beyond doubt, similar to what happens in other artisanal cheeses (Gómez-Ruiz et al., 2002; Lawlor et al., 2002).

Free fatty acids were quantitatively and qualitatively the dominant volatile fraction in ripened Serra da Estrela cheese (Tables 2 and 3), as happens in Manchego cheese, especially when artisanal manufacturing prac- 
Table 2. Compounds tentatively identified by solid phase microextraction-gas chromatography/mass spectroscopy analysis of the volatile fraction of Serra da Estrela cheese throughout ripening; normalized peak areas [(peak area/internal standard peak area)/DM] are averages of 2 replicates.

\begin{tabular}{|c|c|c|c|c|c|}
\hline \multirow[b]{2}{*}{ Compound } & \multirow[b]{2}{*}{$\mathrm{RT}^{1}(\min )$} & \multirow[b]{2}{*}{ Ion } & \multicolumn{3}{|c|}{ Ripening time (d) } \\
\hline & & & 0 & 60 & 180 \\
\hline \multicolumn{6}{|l|}{ Ethyl esters } \\
\hline Ethyl butanoate & 9.27 & 88 & 0.00 & 0.13 & 0.18 \\
\hline Ethyl pentanoate & 9.30 & 85 & 0.00 & 0.07 & 0.11 \\
\hline Ethyl hexanoate & 16.92 & 88 & 2.22 & 0.80 & 1.16 \\
\hline Ethyl octanoate & 28.78 & 88 & 3.16 & 1.15 & 1.81 \\
\hline Ethyl decanoate & 40.72 & 88 & 3.85 & 2.02 & 3.28 \\
\hline Ethyl dodecanoate & 51.81 & 88 & 0.45 & 0.44 & 1.20 \\
\hline \multicolumn{6}{|l|}{ Ketones } \\
\hline 2-Heptanone & 14.17 & 85 & 0.01 & 0.08 & 0.58 \\
\hline 2-Nonanone & 25.82 & 85 & 0.01 & 0.16 & 1.37 \\
\hline 2-Undecanone & 38.22 & 85 & 0.01 & 0.08 & 0.78 \\
\hline \multicolumn{6}{|l|}{ Phenolic compounds } \\
\hline 2,4-Dimethylbenzene & 11.78 & 105 & 0.36 & 0.17 & 0.36 \\
\hline 1,2,4-Trimethylbenzene & 15.86 & 105 & 0.94 & 0.56 & 1.66 \\
\hline Benzoic acid & 78.64 & 105 & 1.30 & 5.05 & 4.65 \\
\hline \multicolumn{6}{|l|}{ Alcohols } \\
\hline 1-Decanethiol & 3.23 & 57 & 0.13 & 0.36 & 0.88 \\
\hline 2-Phenylethanol & 55.13 & 91 & 1.39 & 20.85 & 11.40 \\
\hline Phenol & 59.92 & 94 & 0.18 & 0.43 & 0.73 \\
\hline 4-Methyl phenol & 63.56 & 108 & 0.14 & 0.47 & 0.59 \\
\hline Benzyl alcohol & 63.89 & 108 & 0.08 & 0.31 & 0.60 \\
\hline 4-Methyl-4-nonanol & 80.85 & 57 & 0.49 & 0.35 & 1.99 \\
\hline \multicolumn{6}{|l|}{ Pyrazines } \\
\hline 2,5-Dimethylpyrazine & 22.20 & 108 & 0.01 & 0.10 & 5.44 \\
\hline Trimethylpyrazine & 26.83 & 122 & 0.01 & 0.04 & 3.30 \\
\hline Diethylpyrazine & 30.90 & 136 & 0.00 & 0.00 & 2.27 \\
\hline \multicolumn{6}{|l|}{ Aldehydes } \\
\hline 2-Hydroxy-4-methylbenzaldehyde & 29.19 & 136 & 0.00 & 0.00 & 1.20 \\
\hline 2,4-Decadienal & 30.74 & 81 & 0.20 & 0.22 & 0.21 \\
\hline 2,4-Octadienal & 32.35 & 81 & 0.67 & 0.78 & 0.48 \\
\hline 2,4-Nonadienal & 49.85 & 81 & 0.20 & 0.38 & 1.06 \\
\hline 3,7-Dimethyl 7-octenal & 50.22 & 81 & 0.27 & 0.13 & 0.26 \\
\hline 2,4-Dodecadienal & 55.40 & 81 & 0.06 & 0.03 & 0.14 \\
\hline Octadecanal & 60.48 & 81 & 0.10 & 0.08 & 0.15 \\
\hline \multicolumn{6}{|l|}{ Sulfur derivatives } \\
\hline Dimethyldisulfide & 66.26 & 94 & 0.07 & 0.05 & 0.11 \\
\hline
\end{tabular}

${ }^{1} \mathrm{RT}=$ Retention time.

tices were followed (Gómez-Ruiz et al., 2002). Replacement of whole milk with skim milk has proven that milk fat is an essential prerequisite for flavor develop- ment (Fox et al., 1995). Free fatty acids may derive from lipid catabolism, be biosynthesized from acetylCoA, or appear as the result of metabolism of lactose

Table 3. Concentration of FFA (mg/kg of cheese DM) in the volatile fraction of Serra da Estrela cheese throughout ripening; concentrations are averages of 2 replicates.

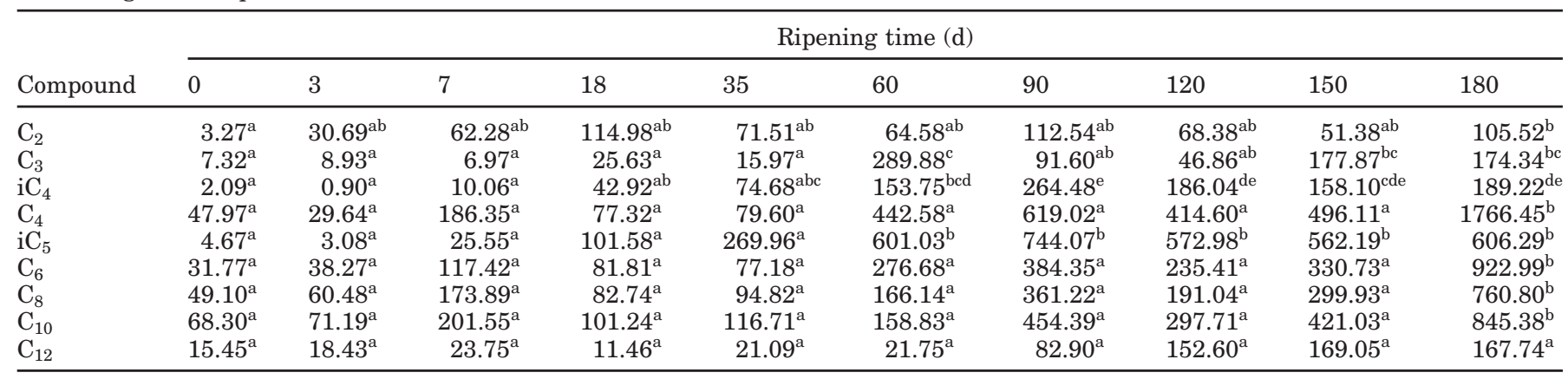

a,b,c,d,e Means in the same row without a common letter are significantly different $(P<0.05)$. 
Table 4. Response factor and fractional recovery of each FFA obtained by solid phase microextraction-gas chromatography/mass spectroscopy from the volatile fraction of Serra da Estrela cheese.

\begin{tabular}{lcl}
\hline Fatty acid & Response factor & Recovery $(\%)$ \\
\hline Acetic acid $\left(\mathrm{C}_{2}\right)$ & 4.11 & 23.0 \\
Propionic acid $\left(\mathrm{C}_{3}\right)$ & 114.52 & 76.0 \\
Isobutyric acid $\left(\mathrm{iC}_{4}\right)$ & 33.63 & 64.6 \\
Butyric acid $\left(\mathrm{C}_{4}\right)$ & 42.78 & 86.9 \\
Isovaleric acid $\left(\mathrm{iC}_{5}\right)$ & 26.97 & 64.7 \\
Caproic acid $\left(\mathrm{C}_{6}\right)$ & 20.53 & 81.9 \\
Caprylic acid $\left(\mathrm{C}_{8}\right)$ & 19.55 & 85.1 \\
Capric acid $\left(\mathrm{C}_{10}\right)$ & 22.58 & 81.9 \\
Lauric acid $\left(\mathrm{C}_{12}\right)$ & 48.03 & 60.7 \\
\hline
\end{tabular}

and lactic acid (e.g., butanoic, propanoic, and acetic acids) or amino acids, mainly leucine and valine, which together represent about $60 \%$ of the free amino acid pool in this cheese (Tavaria et al., 2003). Furthermore, the $\mathrm{pH}$ prevailing in cheese exerts a considerable influence on the flavor impact of FFA; by $60 \mathrm{~d}$ of ripening, $\mathrm{pH}$ is $\sim 5.2$ and a considerable portion of FFA is present in salt form (Fox et al., 1995), hence having little impact on aroma. At longer ripening times, $\mathrm{pH}$ decreases down to 4.8, so FFA are mainly in their protonated forms, thus causing a stronger impact on aroma.

The average amounts of FFA along the ripening process are tabulated in Table 3; letters represent the result of posthoc comparisons (Tukey HSD) between ripening times. Most FFA (i.e., $\mathrm{C}_{2}, \mathrm{C}_{4}, \mathrm{C}_{6}, \mathrm{C}_{8}$, and $\mathrm{C}_{10}$ ) attained their highest concentrations by $180 \mathrm{~d}$ of ripening, hence indicating that their amounts increased with ripening. The amount found by this time was significantly different from those at all other times, thus suggesting that even-chain FFA are biosynthesized directly from acetyl-CoA or are the direct result of the metabolism of lactose, whereas $\mathrm{iC}_{4}$ and $\mathrm{iC}_{5}$ are probably formed from amino acid conversion (from valine and leucine, respectively). The concentration of such FFA in the cheese matrix tends to stabilize between 60 and
$90 \mathrm{~d}$ of ripening; apparently, the presence of leucine and valine (Tavaria et al., 2003) is the rate-limiting step toward formation of FFA. From this table, it is also possible to infer the lipolytic index (amount released per day) associated with FFA. Acetic, caproic, caprylic, and capric acids attained the highest value for that index by $7 \mathrm{~d}$ of ripening $(9.1,20,28$, and $33 \mathrm{mg} / \mathrm{kg}$ per $\mathrm{d}$, respectively). The other short-chain FFA (which are the major contributors to the volatile fraction) reached the highest values between 35 and $60 \mathrm{~d}$ of ripening (time at which this cheese is usually commercialized). Free fatty acids contribute directly to cheese flavor but also serve as precursors for a variety of other compounds, for example, alcohols, esters, aldehydes, ketones, and lactones (Martínez-Castro et al., 1991; Molimard and Spinnler, 1996; Urbach, 1997). Therefore, the origin of FFA in Serra da Estrela cheese is likely attributable to enzymatic biosynthesis or to enzymatic catabolism of free amino acids. Enzymes can exist inside microbial whole cells, or be released following bacterial lysis. The response factors for each FFA, as well as the percentage recovered are tabulated in Table 4.

Esters arise from esterification of FFA with ethanol. Ethanol may originate from lactose fermentation by several homofermentative bacteria, e.g., enterococci and lactobacilli, yeasts and Leuconostoc spp. Large quantities of ethanol and esters are normally associated with fruity flavors (Urbach, 1997). Odor activity values were determined for FFA (Table 5), and were highest for butyric and isovaleric acids by 180 and $90 \mathrm{~d}$ of ripening, respectively. Their OAV reached 88 and 232 by $90 \mathrm{~d}$, and 143 and 95 by $180 \mathrm{~d}$ of ripening, for butyric and isovaleric acids, respectively. Interestingly, the OAV are maximum (Figure 3 ) for $\mathrm{C}_{4}, \mathrm{iC}_{5}$, and $\mathrm{C}_{10}$. Although it has been shown elsewhere (Macedo and Malcata, 1996; Sousa et al., 1997) that long chain, saturated (C16:0 and C18:0), and unsaturated (C18:1, C18:2, and C18:3) FFA are the most abundant in this type of cheese, it is well known that the aroma impact of me-

Table 5. Odor activity values of FFA in the volatile fraction of Serra da Estrela cheese throughout ripening.

\begin{tabular}{|c|c|c|c|c|c|c|c|c|c|c|c|}
\hline \multirow[b]{2}{*}{ Compound } & \multirow{2}{*}{$\begin{array}{l}\text { Odor } \\
\text { threshold }^{1} \\
(\mathrm{ppm})\end{array}$} & \multicolumn{10}{|c|}{ Odor activity values } \\
\hline & & 0 & 3 & 7 & 18 & 35 & 60 & 90 & 120 & 150 & 180 \\
\hline $\mathrm{U}_{2}$ & 54.0 & 0.06 & 0.57 & 1.15 & 2.13 & 1.32 & 1.20 & 2.08 & 1.27 & 0.95 & 1.18 \\
\hline $\mathrm{C}_{3}$ & $40.30^{\mathrm{a}}$ & 0.18 & 0.22 & 0.17 & 0.64 & 0.40 & 7.19 & 2.27 & 1.16 & 4.41 & 2.53 \\
\hline $\mathrm{iC}_{4}$ & $5.30^{\mathrm{a}}$ & 0.40 & 0.17 & 1.90 & 8.10 & 14.09 & 29.01 & 49.90 & 35.10 & 29.83 & 20.91 \\
\hline $\mathrm{C}_{4}$ & $7.00^{\mathrm{a}}$ & 6.85 & 4.23 & 26.62 & 11.05 & 11.37 & 63.23 & 88.43 & 59.23 & 70.87 & 143.25 \\
\hline $\mathrm{iC}_{5}$ & $3.20^{\mathrm{b}}$ & 1.46 & 0.96 & 7.98 & 31.74 & 84.36 & 187.82 & 232.52 & 179.05 & 175.68 & 95.53 \\
\hline $\mathrm{C}_{6}$ & $15.00^{\mathrm{a}}$ & 2.12 & 2.55 & 7.83 & 5.45 & 5.15 & 18.45 & 25.62 & 15.69 & 22.05 & 33.04 \\
\hline $\mathrm{C}_{8}$ & $19.00^{\mathrm{a}}$ & 2.58 & 3.18 & 9.15 & 4.35 & 4.99 & 8.74 & 19.01 & 10.05 & 15.79 & 19.83 \\
\hline $\mathrm{C}_{10}$ & $4.00^{\mathrm{a}}$ & 17.07 & 17.80 & 50.39 & 25.31 & 29.18 & 39.71 & 113.60 & 74.43 & 105.26 & 152.30 \\
\hline $\mathrm{C}_{12}$ & $16.00^{\mathrm{a}}$ & 0.97 & 1.15 & 1.48 & 0.72 & 1.32 & 1.36 & 5.18 & 9.54 & 10.57 & 15.00 \\
\hline
\end{tabular}

${ }^{1}$ Values indicated with ${ }^{a}$ are odor threshold values according to Molimard, Le Quérè, and Spinnler (1997); values indicated with ${ }^{b}$ are odor threshold values according to Thierry et al. (2004). 


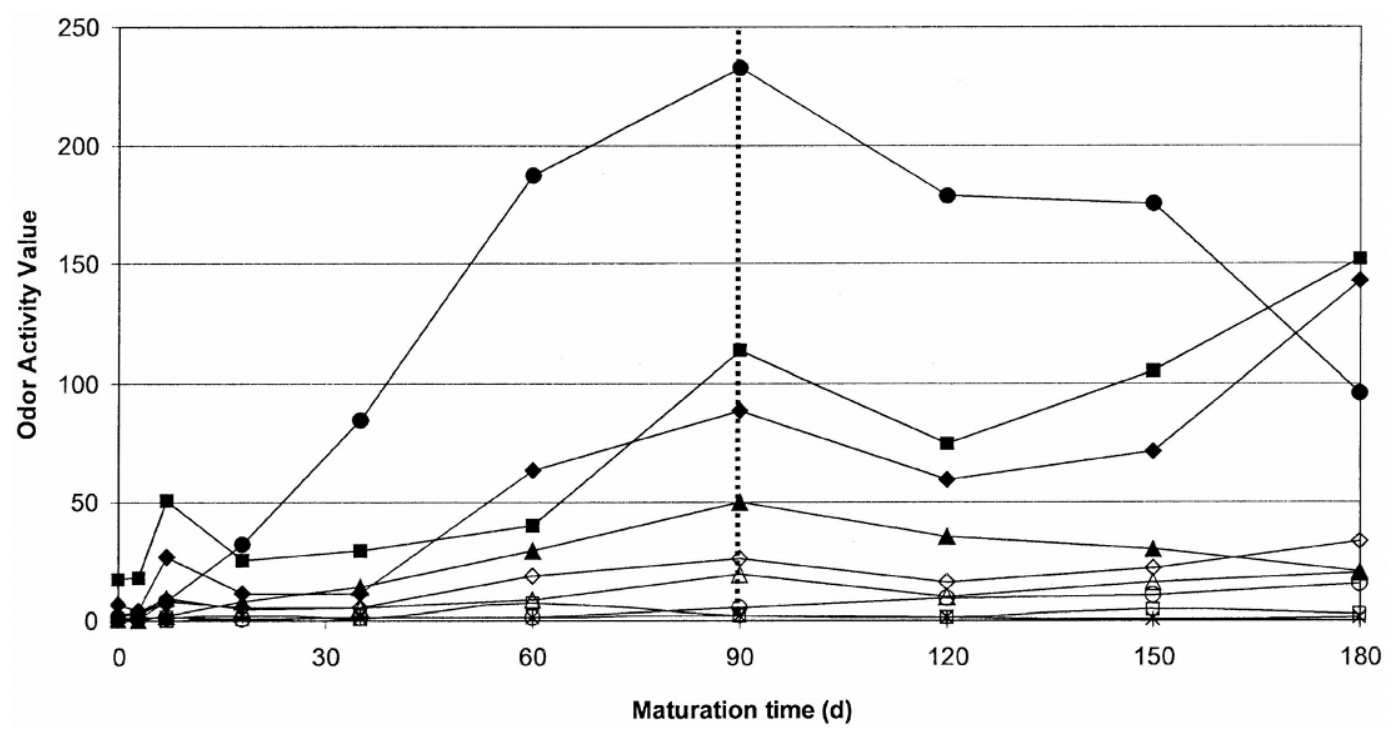

Figure 3. Odor activity values of FFA: acetic (*); propionic $(\square)$; isobutyric $(\mathbf{\Delta})$; butyric $(\diamond)$; isovaleric $(\bullet)$; caproic $(\diamond)$; caprylic $(\triangle)$; capric (ם); and lauric $(\bigcirc)$ acids in Serra da Estrela cheese throughout ripening. The dashed line represents the time at which the aroma impact is maximum.

dium chain FFA is limited due to their relatively low volatility. The time of ripening at which the OAV reach their maximum is represented in Figure 3; this falls between 60 and $90 \mathrm{~d}$, which coincides with the typical consumption time of the cheese.

\section{Sensory Analysis}

To perform sensory tests, we have selected 2 shortchain fatty acids with the highest OAV (butyric and isovaleric acids) and a third compound with a negligible impact upon the sensory perception of this cheese (ethyl hexanoate). ANOVA proved that the panel was homogeneous, and that differences between the samples analyzed were statistically significant $(P<0.05)$. Afterwards, a pairwise comparison was performed involving each set of compounds, using the Kruskal-Wallis test. Results indicate that the panelists were able to detect differences between unripened (control) and reconstituted cheese (i.e., unripened cheese + butyric acid + isovaleric acid + ethyl hexanoate), as well as between the latter and ripened cheese. No significant differences were found between unripened cheese with added $\mathrm{C}_{4}$ and unripened cheese with added $\mathrm{iC}_{5}$. This means that the aroma perception of both is similar, whereas the aroma perception of ethyl hexanoate alone is poor (the sample with added ethyl hexanoate received the same rating as the control sample, as expected). Samples containing one of the FFA plus ethyl hexanoate were also rated low.

The panelists' evaluation placed the samples in 3 different subsets (Table 6): one that included only the reference sample; another that included the reconstituted sample, the one with both acids and the one with isovaleric acid only (closest to the reference sample); and the remaining one that comprised all other samples (closest to the control sample). Butyric and isovaleric acids can be related to the overall aroma of Serra da Estrela cheese, as they are the major FFA present (approximately $48 \%$ of the total) by $60 \mathrm{~d}$ of ripening; due to their $\mathrm{OAV}$, they do indeed contribute to a great extent toward the overall aroma.

Based on the relative amounts of FFA present in Serra da Estrela cheese and on their flavor impact, it can be concluded that the appropriate ripening time for consumption of this cheese is at least $60 \mathrm{~d}$ following manufacture. Furthermore, our results suggest that FFA can be used as ripening indicators for this gourmet cheese, as well as quality indicators, owing to the importance ascribed to the lipolytic keynotes in the Portuguese standard for this cheese.

Table 6. Homogeneous subsets obtained by Tukey's Honestly Significantly Different test.

\begin{tabular}{ll}
\hline Control & $2.09^{\mathrm{a}}$ \\
$\mathrm{C}_{4}+\mathrm{C}_{6} \mathrm{C}_{2}$ & $3.82^{\mathrm{ab}}$ \\
$\mathrm{C}_{4}$ & $3.95^{\mathrm{ab}}$ \\
$\mathrm{C}_{6} \mathrm{C}_{2}$ & $4.00^{\mathrm{ab}}$ \\
$\mathrm{iC}_{5}+\mathrm{C}_{6} \mathrm{C}_{2}$ & $4.23^{\mathrm{ab}}$ \\
$\mathrm{C}_{4}+\mathrm{iC}_{5}+\mathrm{C}_{6} \mathrm{C}_{2}$ & $4.50^{\mathrm{b}}$ \\
$\mathrm{iC}_{5}$ & $4.54^{\mathrm{b}}$ \\
$\mathrm{C}_{4}+\mathrm{iC}_{5}$ & $5.18^{\mathrm{b}}$ \\
Reference & $8.32^{\mathrm{c}}$ \\
\hline
\end{tabular}

a,b,c Means without a common letter are significantly different $(P<$ $0.05)$. 


\section{ACKNOWLEDGMENTS}

The first author gratefully acknowledges the Foundation for Science and Technology (FCT, Portugal) for funding through program PRAXIS XXI ( $\mathrm{Ph}$. D. fellowship BD/9572/96). The European Commission is hereby acknowledged for partial funding through project Control, acceleration and diversification of cheese flavour formed by enzymatic conversion of amino acids (FAIRCT 97-3173). Major funding for this research effort was received via project ENTEROCOCOS: Deepening the knowledge on the role of Enterococci, from manufacture through maturation of traditional cheeses (POCTI/ AGR/36165/99) (FCT), with financial co-participation by FEDER (EU).

\section{REFERENCES}

Akin, N., S. Aydemir, C. Koçak, and M. Yildiz. 2003. Changes of free fatty acid contents and sensory properties of white pickled cheese during ripening. Food Chem. 80:70-83.

Biss, K. 1991. Sheep and goat cheese. J. Soc. Dairy Technol. 44:104-106.

Buchin, S., V. Delague, G. Duboz, J. L. Berdagué, E. Beuvier, S. Pochet, and R. Grappin. 1998. Influence of pasteurization and fat composition of milk on the volatile compounds and flavor characteristics of a semi-hard cheese. J. Dairy Sci. 81:3097-3108.

Centeno, J. A., S. Menéndez, M. Hermida, and J. L. Rodríguez-Otero. 1999. Effects of addition of Enterococcus faecalis in Cebreiro cheese manufacture. Int. J. Food Microbiol. 48:97-111.

Centeno, J. A., S. Menéndez, and J. L. Rodríguez-Otero. 1996. Main microbial flora present as natural starters in Cebreiro raw cow'smilk cheese (Northwest Spain). Int. J. Food Microbiol. 33:307313.

di Cagno, R., J. Banks, L. Sheehan, P. F. Fox, E. Y. Brechany, A. Corsetti, and M. Gobbetti. 2003. Comparison of the microbiological, compositional, biochemical, volatile profile and sensory characteristics of three Italian PDO ewe's milk cheeses. Int. Dairy J. 13:961-972.

Dirinck, P., and A. de Winne. 1999. Flavour characterization and classification of cheeses by gas chromatographic-mass spectrometric profiling. J. Chromatogr. A 847:203-208.

FIL-IDF. 1982. Cheese and processed cheese. Determination of the total solids content. Standard 4A. International Dairy Federation, Brussels, Belgium.

Fox, P. F., J. Law, P. L. H. McSweeney, and J. Wallace. 1993. Biochemistry of cheese ripening. Pages 389-438 in Cheese: Chemistry, Physics and Microbiology. Vol. 1. P. F. Fox, ed. Chapman and Hall, London, UK.

Fox, P. F., T. K. Singh, and P. L. H. McSweeney. 1995. Biogenesis of flavour compounds in cheese. Pages 59-97 in Chemistry of Structure-Function Relationships in Cheese. Vol. 1. E. I. Malin and M. H. Tunick, ed. Plenum Press, New York, NY.

Gómez-Ruiz, J. A., C. Ballesteros, M. A. González-Vinãs, L. Cabezas, and I. Martínez-Castro. 2002. Relationships between volatile compounds and odour in Manchego cheese: Comparison between artisanal and industrial cheeses at different ripening times. Lait 82:613-628.

Grappin, R., and E. Beuvier. 1997. Possible implications of milk pasteurization on the manufacture and sensory quality of ripened cheese: A review. Int. Dairy J. 7:751-761.

Lawlor, J. B., C. M. Delahunty, M. G. Wilkinson, and J. Sheehan. 2002. Relationships between the gross, non-volatile and volatile compositions and the sensory attributes of eight hard-type cheeses. Int. Dairy J. 12:493-509.

Macedo, A. C., and F. X. Malcata. 1996. Changes in the major free fatty acids in Serra cheese during ripening. Int. Dairy J. 6:1087-1097.

Martínez-Castro, I., J. Sanz, L. Amigo, M. Ramos, and P. MartínAlvarez. 1991. Volatile compounds of Manchego cheese. J. Dairy Res. 58:239-246.

Menéndez, S., J. A. Centeno, R. Godínez, and J. L. Rodríguez-Otero. 2000. Effects of various Lactobacillus strains on the ripening and organoleptic characteristics of Arzua-Ulloa cheese. Int. J. Food Microbiol. 59:37-46.

Menéndez, S., J. A. Centeno, R. Godínez, and J. L. Rodríguez-Otero. 1999. Use of autochthonous Lactococcus lactis strains as starters for Arzua-Ulloa cheese manufacture. Microbiol. Alim. Nutr. $17: 59-70$.

Molimard, P., and H. E. Spinnler. 1996. Review: Compounds involved in the flavor of surface mold-ripened cheeses: Origins and properties. J. Dairy Sci. 79:169-184.

Muñoz, N., M. Ortigosa, P. Torre, and J. M. Izco. 2003. Free amino acids and volatile compounds in an ewe's milk cheese as affected by seasonal and cheese-making plant variations. Food Chem. 83:329-338.

NP-1922 (Norma Portuguesa. Queijo Serra da Estrela. Definicão, características e marcação). 1985. Direcção-Geral da Qualidade. Diário da República série III, No. 30.

Ortigosa, M., P. Torre, and J. M. Izco. 2001. Effect of pasteurization of ewe's milk and use of a native starter culture on the volatile components and sensory characteristics of Roncal cheese. J. Dairy Sci. 84:1320-1330.

Partidário, A. M., M. Barbosa, and L. Vilas-Boas. 1998. Free fatty acids, triglycerides and volatile compounds in Serra da Estrela cheese - changes throughout ripening. Int. Dairy J. 8:873-881.

Pèrés, C., C. Denoyer, P. Tournayre, and J. L. Berdagué. 2002. Fast characterization of cheeses by dynamic headspace-mass spectrometry. Anal. Chem. 74:1386-1392.

Pinho, O., I. M. Ferreira, S. Casal, J. O. Fernandes, M. B. Oliveira, and M. A. Ferreira. 2001. Method optimization for analysis of the volatile fraction of ewe cheese by solid-phase microextraction. Chromatographia 53:390-393.

Sousa, M. J., V. M. Balcão, and F. X. Malcata. 1997. Evolution of free fatty acid profile during ripening in cheeses manufactured from bovine, ovine and caprine milks with extracts of Cynara cardunculus as coagulant. Z. Lebensm. Unters. Forsch. A 205:104-107.

Tavaria, F. K., I. Franco, F. J. Carballo, and F. X. Malcata. 2003. Amino acid and soluble nitrogen evolution throughout ripening of Serra da Estrela cheese. Int. Dairy J. 13:537-545.

Tavaria, F. K., and F. X. Malcata. 1998. Microbiological characterization of Serra da Estrela cheese throughout its Appéllation d'Origine Protégée region. J. Food Prot. 61:601-607.

Urbach, G. 1997. The flavour of milk and dairy products. 2. Cheese: contribution of volatile compounds. Int. J. Dairy Technol. 50:79-89. 